\title{
AAAS members fret over links with theological foundation
}

Washington

Leading members of the American Association for the Advancement of Science (AAAS) are questioning the nature of its involvement in a programme on science and religion backed by the controversial John Templeton Foundation.

The foundation promotes "a path of cooperation" between the sciences and religion, funding up to 100 interdisciplinary courses each year and publishing a newsletter called Progress in Theology. Its other beneficiaries include an annual \$1.24 million prize for progress in religion, and a study of the benefits of private enterprise called the Freedom Project.

The AAAS's physics section forced a public review of the association's $\$ 2$ million Program of Dialogue on Science, Ethics and Religion at the annual meeting of its governing council last Sunday (20 February). Some questioned the programme's independence from the Templeton Foundation, and challenged its consistency with the association's aims.

But they accepted assurances from AAAS president Stephen Jay Gould and Al Teich, head of its science policy division, that steps are being taken to bolster the programme's independence.

The programme has supported a number of activities aimed at developing a dialogue between science and religion. It was set up four years ago with initial support from the John Templeton Foundation. So far, it has attracted \$1.1 million from the foundation and $\$ 950,000$ from other sources

The physicists are claiming a conflict of interest between the AAAS, whose mission is to promote science, and the Templeton Foundation, which — said Hans Frauenfelder, a physicist at the Los Alamos national laboratory in New Mexico and past chairman of the AAAS physics section - believes there will ultimately be a "rapprochement" between science and religion.

"We are concerned that the Templeton Foundation has exercised undue influence on the programme," adds John Peoples, former director of Fermilab in Illinois and current chairman of the AAAS physics section. "At a bare minimum, we feel that there is a conflict between the values and goals of the Templeton Foundation and those of the AAAS." Frauenfelder presented data suggesting that speakers at meetings convened by the programme were often associated with the Templeton Foundation.

According to Rolf Sinclair, past secretary of the physics division, six people have served on the advisory boards to both the AAAS

programme and the foundation. Sinclair says that several nominations by the physics division to the advisory board have been summarily rejected. "I don't think it is an advisory committee: it is a committee of people involved in the programme," he says.

But Al Teich, head of science policy at the AAAS, defended the programme vigorously. "This is a very religious country," he told the council. "Religious leaders are listened to. Their views are very important and we need to talk to them if science is going to be influential and take a role in shaping our lives."

Teich said that the programme was currently applying for $\$ 500,000$ of additional outside support. If obtained, this would allow it to reach its objective of restricting Templeton Foundation support to 40 per cent of the total.

Joel Primack, a physicist at the University of California at Santa Cruz and the new chairman of the programme's advisory committee, says that the number of its members who also advise the Templeton Foundation had been cut to one.

He cited the programme's interest in environmental matters, which Templeton refuses to support, as evidence of its independence. "The areas we think are important are in no way influenced by the Templeton Foundation," he says.

But Gould came close to admitting that the original decision to accept so much support from the foundation was a mistake. Responding to a question about Templeton's aims, he said: "My sense is that, although they attach no strings [to their money], their interest is to find that great, inevitable position that will bring science and religion together.

That is totally wrong in my view. But what's done is done." Gould added that the programme was "now on the right path".

Colin Macilwain

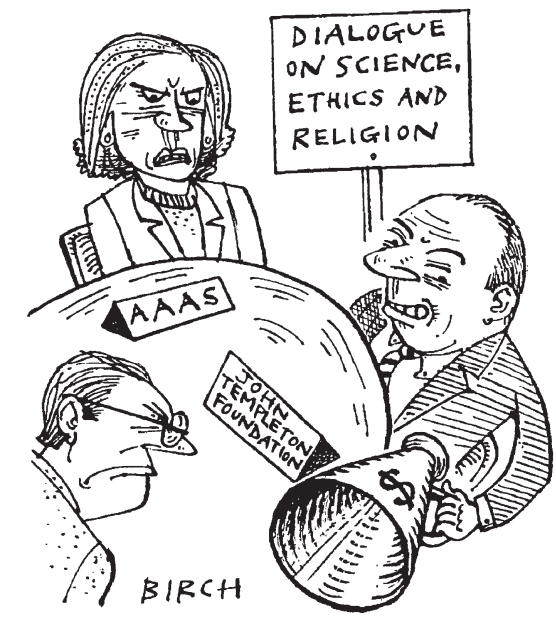

ผ () 2000 Macmillan Magazines Ltd
Japan set to tighten ethics rules for genetic sampling

\section{Tokyo}

Researchers working on human genetics in Japan will be required for the first time to obtain the informed consent of those providing samples, under draft ethics guidelines released by the Ministry of Health and Welfare last week.

But several leading geneticists have already criticized the guidelines as not doing enough to reassure research subjects that their genetic information will not be misused.

The guidelines are a response to a large project, funded by the ministry, to collect data on single nucleotide polymorphisms (SNPs), due to begin in April. They also follow newspaper articles criticizing various institutions for doing genetic research on human samples without the proper consent of those from whom they were obtained.

The guidelines apply only to research funded by the health ministry. If they are broken, the directors of the institute or hospital in question will be able to stop the project and confiscate its funding.

An ethics panel at the Council for Science and Technology is drawing up similar guidelines. The council advises the Science and Technology Agency - the main funding body for human-genome research in Japan.

Earlier this month, researchers at the National Cardiovascular Center in Osaka, the University of Kyushu, Fukuoka, and Tohoku University, Sendai, admitted that they have used thousands of blood samples for analysis without informing patients.

The revelations have prompted an intense media debate, and observers say that the scientists may have gone public in anticipation of the guidelines. These specify that it is up to institutional ethics boards to decide on the use of samples obtained in the past and without permission.

Scientists at Tohoku University, who halted a research project on the genetics of cerebral apoplexy last autumn to consult the university's ethics board and explain the situation to concerned patients, have declared that they intend to resume research in the next few weeks.

But critics of the guidelines argue that rules on informed consent will not convince patients that their privacy will be protected - particularly as Japan lacks data-protection laws.

"The focus is mainly on how to obtain and how to use human material," says 
Yusuke Nakamura, who directs a large SNPs project at Tokyo University's Institute of Medical Science. "But it is unclear how to ensure the rights of patients, and how to deal with patients whose privacy has been violated, and who may be subject to various forms of genetic discrimination."

Nakamura says that many patients are afraid to provide samples, following speculation that genetics research could lead to social discrimination. "Legal regulation, including penalties for those who do not comply, should be established as soon as possible," he says.

Some observers fear that insufficient regulation could provoke further media criticism, making it harder to obtain human samples. The supply of these is hindered by a lack of links between scientists and clinicians.

"Much recent trouble concerning human samples has been caused by a lack of communication between medical doctors and researchers," says Yoshihide Hayashizaki, who leads the Genome Exploration Research Group at RIKEN's Genomic Sciences Center.

Nobuyoshi Shimizu, who directs the Center for Genomic Medicine at the Keio University School of Medicine, says that it is "difficult to obtain fresh tissue samples". He argues that national facilities are needed to prevent the commercialization of the supply of human tissue samples.

Guidelines for the use of human cells and tissues were published last year by an ethics panel at the Japan Tissue Culture Association, headed by Toshiharu Matsumura, a general manager at the Meiji Cell Technology Center. Matsumura sees them as a "first step" towards a regulatory framework. Robert Triendl

\section{Gene therapy institute denies that errors led to trial death}

Washington

The director of the gene therapy institute where a patient died during treatment last September has admitted errors in the administration of its trials, but denies that they led to the patient's death.

The US Food and Drug Administration (FDA) recently shut down five clinical trials at the University of Pennsylvania's Institute of Human Gene Therapy (IHGT) after an investigation found 18 possible violations in the way the institute had run and monitored an earlier trial (see Nature 403, 354; 2000).

In a letter to the FDA, James Wilson, director of the institute, acknowledges errors in the trial - the first in which a death has been attributed directly to the experimental treatment (see Nature 401, 517; 1999).

Wilson does not not accept all 18 of the FDA's preliminary findings, but he admits perhaps the most serious charge: that the institute failed to contact the FDA when two patients who received an adenoviral vector with a therapeutic gene for a liver-enzyme deficiency experienced adverse effects.

Under the protocol, the IHGT should have notified the FDA immediately. Wilson says that the institute had reported similar effects in two previous patients, and that the FDA had allowed the trial to resume in both cases. He points out that the FDA received written records of those adverse effects before permitting the IHGT to use higher doses on other patients, but wrote that "IHGT should not have proceeded as it did".

But Wilson denies several other serious charges. For example, he says that Jesse Gelsinger, the Arizona man who died in the

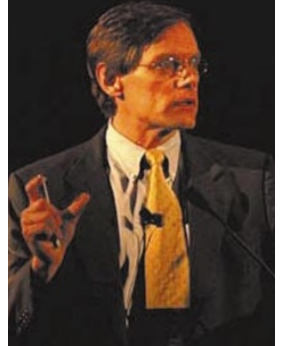

Wilson: admits that procedures were lax. experiment, was eligible for treatment despite having a high level of ammonia before the treatment. The protocol specified only that the enzyme level should be normal at the time of enrolment, not treatment, and it is "common" for such enzyme levels to fluctuate, Wilson says in his letter.

Also, he says that the researchers did not inform Gelsinger of the deaths of two primates because they were models for a different disease and received a different therapeutic gene.

Finally, the university report contradicts Paul Gelsinger, Jesse's father, who, at a recent Senate hearing, said that investigators did not follow procedures for informed consent properly (see Nature 403, 583; 2000). "Each and every patient in the ... trial gave clear and unambiguous consent to participate."

Wilson declined to comment further. But Kenneth Wildes, a university spokesman, says: "We made some mistakes, but those mistakes did not lead to the death of Jesse Gelsinger." Wildes adds: "We're not minimizing the conduct of researchers at Penn. They should be held to the highest standards."

Wilson says in his letter that, if allowed to resume its suspended trials, IHGT would be willing to be more closely monitored, and to follow more stringent reporting requirements.

Paul Smaglik

\section{US physics society puts feisty newsletter in doubt}

\section{Washington}

What's New, a popular and often scurrilous weekly news summary read by more than 10,000 physicists and followers of science policy in the United States and abroad, could cease publication in July, following the American Physical Society's (APS) threat to stop supporting its author, Bob Park.

The APS wrote last month to the physics department at the University of Maryland at College Park, where Park is a professor, saying that it wants to cut its support from twothirds to one-half of his salary.

If that happens, says Park, he will have to increase his teaching and other commitments at the university, and will be unable to continue his work for the APS, which includes the production of What's New. Given the lack of effort involved, he describes the APS letter as "an adiabatic firing".

Park has served as a kind of freelance mouthpiece for the APS for many years. He writes frequent columns for The New York Times and other newspapers on everything from global warming to the recent spying scandal at nuclear weapons laboratories.

Neither the columns nor the What's New electronic newsletter are attributed directly to the APS - the newsletter always ends with Park's signature line: "Opinions are the author's and are not necessarily shared by the APS, but they should be." But they do reflect the views of many physicists, and give the community a rapid response to current events
— lacking in most scientific societies, which can take months to agree a point of view.

As news of the APS plan leaked out during the meeting of the American Association for the Advancement of Science in Washington last week, some physicists were planning to write to the new APS president, Jim Langer, of the University of California at Santa Barbara, to protest at the decision. Some suggest that Park may have offended someone once too often.

Jerome Friedman of the Massachussetts Institute of Technology, last year's APS president, said that he didn't want to discuss the matter "until it was resolved". But he added: "There is no dissatisfaction with Bob — it's a question of resources."

Colin Macilwain 